\title{
Megaclasts: Term Use and Relevant Biases ${ }^{\dagger}$
}

\author{
Dmitry A. Ruban ${ }^{1, * \mathbb{D}}$, Alena A. Ponedelnik ${ }^{1}$ and Natalia N. Yashalova ${ }^{2}$ \\ 1 Department of Business in Hospitality Sphere, Higher School of Business, Southern Federal University, \\ 23-ja linija Street 43, Rostov-on-Don 344019, Russia; studentsrda@mail.ru \\ 2 Department of Economics and Management, Business School, Cherepovets State University, \\ Sovetskiy Avenue 10, Cherepovets, Vologda Region 162600, Russia; natalij2005@mail.ru \\ * Correspondence: ruban-d@mail.ru \\ $+\quad$ This paper is dedicated to the memory of V.I. Pugachev.
}

Received: 20 November 2018; Accepted: 17 December 2018; Published: 27 December 2018

check for updates

\begin{abstract}
The term "megaclast" started circulation near the beginning of the 21st century. The present review is aimed at examination of the use of this term in the modern geoscience literature. The main method is bibliographical survey of the articles published during 2000-2017 with the on-line bibliographical database "Scopus". The main findings are as follows. The term "megaclast" has not been used extensively, but the number of the articles employing this term increased in the mid-2000s and in the early 2010s. The majority of the papers deal with megaclasts of Quaternary age. The megaclast research focuses on five regions, namely West Europe, Australia and New Zealand, Western North America, Southern South America, and the Pacific and circum-Pacific. The most studied are megaclasts occurring on coasts influenced by tsunamis and storms; significant attention has been paid also to those clasts transported by volcanism-triggered debris flows and slope failures, both continental and submarine. There are three serious biases relevant to the use of the term "megaclast" in the geoscience literature, namely stratigraphical, geographical, and genetic biases. Due to this incompleteness in the knowledge of megaclasts, this term should be either used more actively, which is preferable, or abandoned.
\end{abstract}

Keywords: bibliometric approach; large clasts; literature review; research geography; sedimentology

\section{Introduction}

During the two past decades, there have been some important advances to refine nomenclature of sedimentary rocks and particles. Blair and McPherson [1], Farrell et al. [2], and Lokier and Al Junaibi [3] contributed to this issue. It is equally interesting to realize how well the international research community has perceived the novelties and focused on the study of newly-recognized categories of rocks and particles.

Udden [4] and Wentworth [5] developed the approach for classifying clastic grains by size that is still in wide use. However, this approach is less appropriate for particles that reach several meters and dozens of meters in diameter because these should be recognized as a particular category. An interest in such clasts has increased, particularly because of significant intensification of investigations on modern and ancient tsunami deposits [6]. Moreover, erratic "boulders" and olistoliths have remained interesting features for more than a century. Presently, two additional factors stimulate this interest. The importance of the largest stones on the Earth as geological heritage and geotourist attractions has been realized by Wimbledon and Smith-Meyer [7] and Lubova et al. [8]. Large clasts have been found on various cosmic bodies, and these clasts are described, particularly, by Pajola et al. [9], Bruno and Ruban [10], and Dhingra [11]. The studies of the both kinds require detailed description of large clasts. Blair and McPherson [1] proposed a new, detailed classification of sedimentary particles 
larger than $4 \mathrm{~m}$. The discussion started, and later Blair and McPherson [12] updated their scheme, whereas Blott and Pye [13], Terry and Goff [14], and Bruno and Ruban [10] proposed new classifications. All these classifications permit to deal with large clasts in detail and provide new terminology.

The term "megaclast" has become a general term for the largest sedimentary particles (Figure 1). The objective of this article is to review the use of the term "megaclast" in the modern geoscience literature. Particularly, the frequency of the term use, its application to different geological time slices, regions, and depositional environments are to be examined. Such a terminological reflection is necessary in order to understand how the new, and potentially very important, term is used by scientists and whether this use is biased and, thus, has to be improved. The present paper does not focus on solution of the problems with different large clast classifications because this issue was addressed in detail by Bruno and Ruban [10]. This review starts with explanation of the essence of the term "megaclast". Then, parameters of the bibliometric approach employed for the purposes of the present analysis are clarified. Two following sections bear results and inform about the main trends of megaclast research and the spatio-temporal dimension of the term application. The discussion presents further interpretation of the main findings, and it emphasizes the biases of the term use and the geotourism aspect.

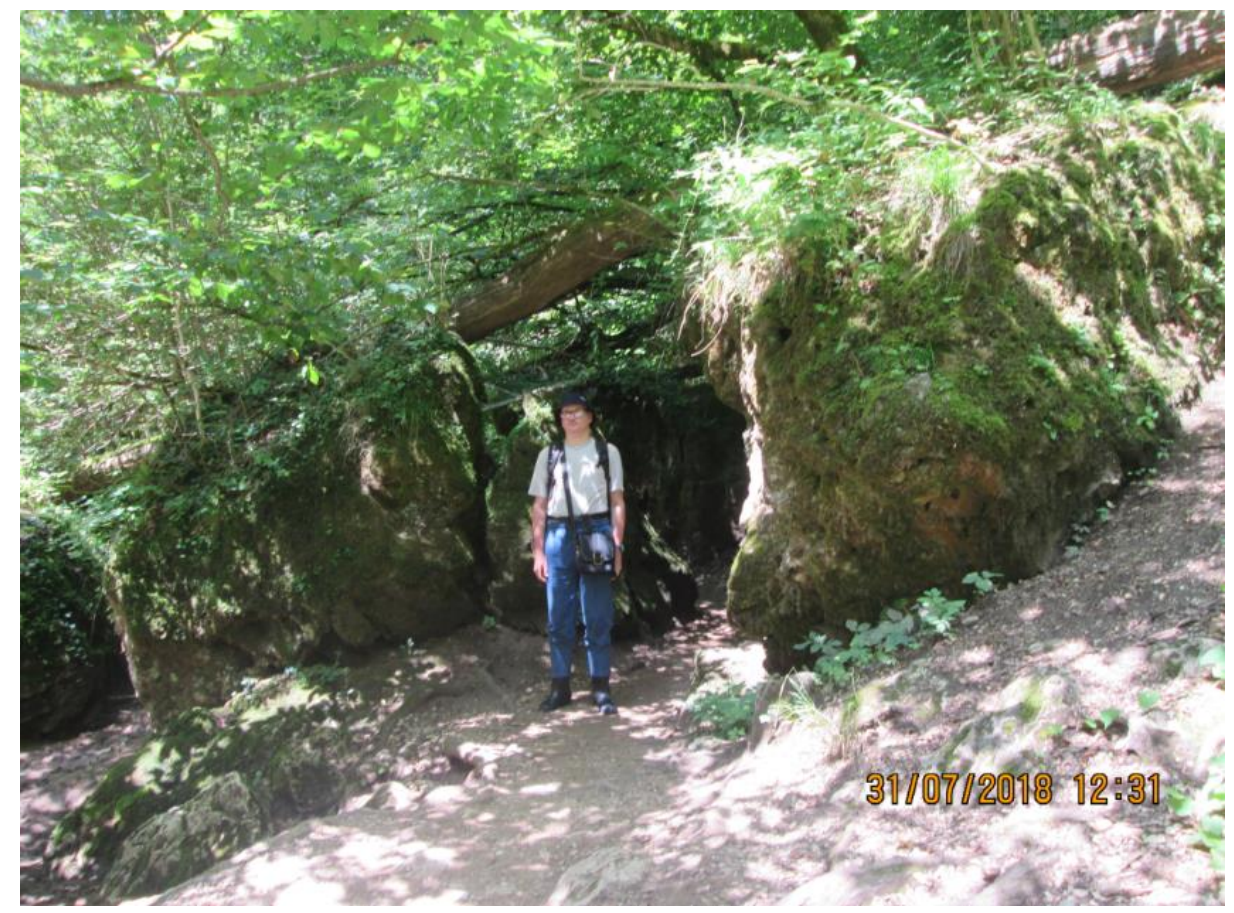

Figure 1. Upper Jurassic limestone megaclasts fallen to the bottom of the Rufabgo Canyon in the Western Caucasus; the person provides a sense of scale (used by permission of N.V. Ruban).

\section{Conceptual Remarks on Megaclasts}

The term "megaclast" was applied in the geological literature here and there, but rarely [15-20]. Conceptual studies by Blair and McPherson [1,12], Blott and Pye [13], Terry and Goff [14], and Bruno and Ruban [10] have promoted this term.

The understanding of megaclasts remains poorly defined. There is no agreement of how to limit the category of megaclasts in a scheme of grain-size classification. Blair and McPherson [1] and Terry and Goff [14] proposed a size of $4.096 \mathrm{~m}$ as the lower limit. This matches the general principle of the Udden-Wentworth scheme. However, Blott and Pye [13] recommended a size of $2.048 \mathrm{~m}$ as the lower limit. Finally, Bruno and Ruban [10] suggested a size of $1 \mathrm{~m}$ as the lower limit of megaclasts, particularly to make the classification suitable for application to distant cosmic bodies. Very different terms have been proposed for naming subdivisions of megaclasts. Each following team of specialists 
expressed concerns about the names suggested by earlier workers. Moreover, the clear separation between boulders, i.e., much smaller clasts, and megaclasts is not fixed in the terminology. For instance, Terry and [14] proposed to identify some megaclasts as mesoboulders and macroboulders, although the latter are not true boulders because boulders are smaller than megaclasts by definition.

Despite the above-mentioned uncertainties, three statements seem to be indisputable. The term "megaclast" is well-suited for description of a separate category or class of grains. The size of megaclasts is measured by meters, dozens of meters, and even hundreds of meters. It is sensible to subdivide this category into several grades. Moreover, it appears that single megaclasts and their accumulations, i.e., clusters or "fields", constitute a specific geological phenomenon, which is aesthetically impressive [21].

\section{Material and Method}

The bibliometric approach is becoming an efficient tool for conceptualization in the modern science, as shown recently by Qiu and Liu [22]. It employs diverse methods and modes of data presentation, some of which seem to be suitable for terminological studies. The present review is based on analysis of literature sources that directly use the term "megaclast". A targeted bibliographical survey, which is a kind of bibliometric approach, was conducted for this purpose. The on-line bibliographical database "Scopus" was searched. This database has an excellent coverage of geoscience journals where papers on megaclasts can be published. This database includes many regional-to-local journals, which fact minimizes missing the necessary publications.

All articles published in professional journals and special publication series during the time period of 2000-2017 and containing the term "megaclast(s)" in their titles, abstracts, and keywords were identified. Fifty four sources were found this way (Table 1), and these seem to be the only published works that employ the term actively. Apparently, these sources reflect the status of megaclast research after the publication of the article by Blair and McPherson [1]. Of course, there are other sources that mention megaclasts occasionally. However, consideration of the incorrect use of the term "megaclast" may result in significant "noise" in the collected bibliographical records that may affect the clarity of the subsequent analysis. In contrast, occurrence of the term "megaclast" in the title, abstract, or keywords means that the article more-or-less focuses on megaclasts. There may be other sources not included into "Scopus", but these are chiefly limited to very local journals or proceedings/abstract volumes, which cannot be judged as full representatives of the international geoscience media. In any case, only a part of them can be found with on-line tools and, thus, their consideration will make the analyzed bibliographical data less representative. Indeed, articles about large clasts were published before 2000, but these do not much anyway the time frame of the present review that is limited to the appears of the paper by Blair and McPherson [1]. It should be added that a few very important articles by Paris et al. [23,24], Ramalho et al. [25], Hearty and Tormey [26], and Cox et al. [27] that are devoted to megaclasts and employ this term, although do not retain it in their titles, are added to the collected sources used for the purposes of the present analysis. Three of these articles are published in 2018, but they became available already in 2017 and, thus, these match the analyzed time frame. As a result, the total number of analyzed articles is 59 (Table 1). 
Table 1. Megaclast-related literature sources for the purposes of examination of the term use.

\begin{tabular}{|c|c|c|c|}
\hline Author(s), Source & Age & Location & Facies/Origin \\
\hline Barbano et al. [28] & $\mathrm{Q}$ & Sicily & Tsunami \\
\hline Bruno and Ruban [10] & - & extraterrestrial bodies & Extraterrestial \\
\hline Canto et al. [29] & $\mathrm{Pg}$ & Philippines & Tectonic \\
\hline Carpentier et al. [30] & $\mathrm{J}$ & France & Storm \\
\hline Choe et al. [31] & $\mathrm{K}$ & Chile & Deep-marine channel \\
\hline Coira and Perez [32] & $\mathrm{O}$ & Argentina & Magma-water interaction \\
\hline Dewey and Ryan [33] & $\mathrm{N}, \mathrm{Q}$ & New Zealand & Tsunami, storm \\
\hline Engel and May [34] & $\mathrm{Q}$ & Caribbean & Tsunami \\
\hline Furlanetto et al. [35] & PPR & northwestern Canada & Tectonic \\
\hline Gaylord and Neall [36] & Q & New Zealand & Volcanic \\
\hline Gaylord et al. [37] & Q & New Zealand & Volcanic \\
\hline Goff and Terry [38] & $\hat{Q}$ & Pacific & Tsunami \\
\hline Hall et al. [39] & Q & British Isles & Coast \\
\hline Hoffmann et al. [40] & $\hat{Q}$ & Arabia & Tsunami \\
\hline Horak and Evans [41] & NPR & British Isles & - \\
\hline Jackson [42] & $\mathrm{CZ}$ & offshore Brazil & Submarine mass wasting \\
\hline Kalnina et al. [43] & $\mathrm{Q}$ & Baltic Region & Glacial erosion \\
\hline Keigler et al. [44] & $\mathrm{Q}$ & New Zealand & Volcanic and mass wasting \\
\hline Laird et al. [45] & $\hat{\mathrm{Pg}}$ & New Zealand & Channel \\
\hline Laughton et al. [46] & PPR & northwestern Canada & Tectonic + volcanic \\
\hline Le Heron et al. [47] & NPR & western United States & Tectonic and ice-rafting \\
\hline Le Heron et al. [48] & NPR & western United States & Tectonic \\
\hline Le Roux [49] & $\mathrm{CZ}$ & Chile & Mass wasting and tsunami \\
\hline Le Roux and Vargas [50] & $\mathrm{N}$ & Chile & Mass wasting and tsunami \\
\hline Lecointre et al. [51] & Q & New Zealand & Volcanic and mass wasting \\
\hline Lorang [52] & - & - & Tsunami and storm \\
\hline Lubova et al. [8] & $\mathrm{Q}$ & Caucasus & Mass wasting \\
\hline Madon [53] & $\hat{\mathrm{T}}$ & Malaysia & Submarine mass wasting \\
\hline Martin-Merino et al. [54] & PZ2 & Spain & Submarine mass wasting \\
\hline McKee et al. [55] & $\mathrm{K}$ & western United States & Mass wasting \\
\hline Medina et al. [56] & Q & Morocco & Tsunami and storm \\
\hline Noormets et al. [57] & Q & Pacific & Tsunami \\
\hline Noormets et al. [58] & $\hat{Q}$ & Pacific & Tsunami \\
\hline Oliveira et al. [59] & Q & Portugal & Storm \\
\hline Ortiz-Karpf et al. [60] & $\hat{\mathrm{Q}}$ & Caribbean & Submarine mass wasting \\
\hline Paris et al. [61] & $\mathrm{Q}$ & Mauritius & Tsunami \\
\hline Perez-Alberti et al. [62] & $\hat{\mathrm{Q}}$ & Spain & Storm \\
\hline Pierre [63] & $\hat{Q}$ & France & Coastal processes \\
\hline Pope and Grotzinger [64] & PPR & northwestern Canada & Evaporite dissolution and mass wasting \\
\hline Preiss et al. [65] & NPR & Australia & Glaciation \\
\hline Roverato et al. [66] & Q & New Zealand & Volcanic and mass wasting \\
\hline Salisbury et al. [67] & $\mathrm{Cm}$ & Australia & Extraterrestrial impact \\
\hline Scheffers et al. [68] & $\mathrm{Q}$ & Australia & Tsunami \\
\hline Scheffers et al. [69] & Q & British Isles & Storm \\
\hline Scheffers et al. [70] & $\mathrm{Q}$ & British Isles & Storm \\
\hline Shane et al. [71] & $\mathrm{N}$ & New Zealand & Submarine mass wasting \\
\hline Suttner and Kido [72] & $\mathrm{D}$ & Alps & Coastal processes \\
\hline Terry and Goff [14] & - & - & - \\
\hline Thorkelson and Laughton [73] & PPR & northwestern Canada & Tectonic \\
\hline Trenhaile [74] & - & - & Coastal processes \\
\hline Weckwerth and Pisarska-Jamrozy [75] & $\mathrm{Q}$ & Poland & Fluvial-periglacial \\
\hline Williams [76] & $\mathrm{Q}$ & British Isles & Storm \\
\hline Williams and Hall [77] & Q & British Isles & Storm \\
\hline Yagishita and Komori [78] & $\hat{\mathrm{N}}$ & Japan & Mass wasting \\
\hline Hearty and Tormey [26] & $\mathrm{Q}$ & Bahamas & Storm \\
\hline Cox et al. [27] & $\hat{Q}$ & Ireland & Storm \\
\hline Paris et al. [23] & - & - & Storm \\
\hline Paris et al. [24] & Q & Cape Verde, Mauritius, Reunion & Tsunami \\
\hline Ramalho et al. [25] & $\mathrm{Q}$ & Cape Verde & Tsunami, coastal processes \\
\hline
\end{tabular}

Age abbreviations: PPR—Paleoproterozoic, NPR—Neoproterozoic, $\mathrm{Cm}-$ Cambrian, O-Ordovician, D-Devonian, PZ2-Late Paleozoic, T-Triassic, J-Jurassic, K-Cretaceous, CZ-Cenozoic, Pg-Paleogene, N-Neogene, Q-Quaternary and Recent.

Undoubtedly, some megaclasts were the focus of research, but these were not recognized as megaclasts-a typical example is the work of Rovere et al. [79]. The other terms such as "boulders" and "blocks" were used. Such articles are not covered by the quantitative analysis of the present 
paper because of two reasons. Their consideration would lead to the unbalanced and unjustified bibliographical dataset. It is of special importance to focus on the use of the term "megaclast" in the modern geoscience literature. However, the above-mentioned articles are discussed in this paper separately, which avoids the problem of missing some important sources.

The content of each identified source was examined and, in particular, checked using certain criteria. The years of publication are considered in order to reconstruct research dynamics. Attention is paid to the geological age and geographical location of megaclasts. Palaeoenvironmental context and/or origin of megaclasts mentioned in the chosen sources are specified. The results of the analysis allow the main parameters of megaclast research to be characterized and to summarize its main outcomes with regard to the spatio-temporal distribution of megaclasts and their relevance to facies and specific geological processes.

\section{Basic Trends of Megaclast Research}

The total number of the megaclast-related articles, i.e., the articles employing the term "megaclast", published during 2000-2017 is relatively low (Table 1). On average, only three articles were published each year during this time frame. However, the intensity of term use was unstable (Figure 2). During the 2000s, the intensity was very low, although the number of the articles increased in the mid-2000s, most probably, as result of interest to tsunami deposits as a consequence of the Indian Ocean Tsunami of 2004 [6]. The situation changed in the 2010s, when the number of articles increased significantly (Figure 2). Although term use tended to decline later, it appears that megaclasts attracted relatively more attention during this decade. Interestingly, this tendency established before the highly-important contributions of Blott and Pye [13] and Terry and Goff [14] were published and, thus, these contributions themselves did not catalyze the noted intensification in research. What is also important is that megaclast-related articles were published each year after 2001, which implies a kind of continuity of interest on this term.

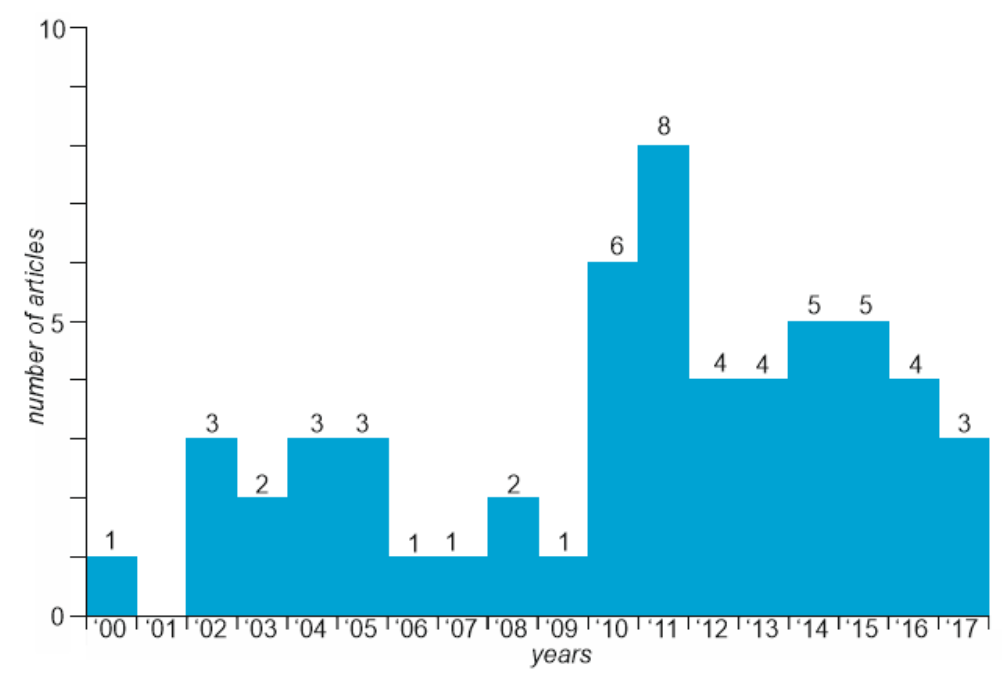

Figure 2. Dynamics of the megaclast-related publishing activity during 2000-2017 (created by authors).

The citation rate of megaclast-related articles is low-to-moderate. As the most representative example, it is possible to say that the work of Blair and McPherson [1] was cited only 165 times during 18 years, and not always in relevance to large clasts. The articles of Barbano et al. [28], Noormets et al. [57,58], and Williams and Hall [77] are among the most successful articles in regard to the number of citations. Many others can boast not more than 10 citations. This evidence also implies relative weakness in the areas of megaclast research.

Those articles analyzed appear to be diverse, thematically. Although many focus on megaclasts as indicators of coastal susceptibility to tsunamis and storms, others deal with a wide range of 
topics. The latter include continental and submarine slope processes, evolution of volcano edifices, Neoproterozoic glaciations, terrane accretion, extraterrestrial environments, etc. Thematic diversity is related chiefly to discussion of megaclasts of different ages and in connection with different geological processes (Table 1). Of special importance is the appearance of a series of conceptual papers. Some of them are directly concerned with megaclasts. For instance, Terry and Goff [14] focused on megaclast-related nomenclatures and Bruno and Ruban [10] critically reviewed megaclast studies on various cosmic bodies. Articles by Noormets et al. [57,58] provide almost classical discussions of megaclast transport relevant to tsunamis. These are complemented by the work of Le Roux and Vargas [49]. Another conceptually important topic draws a distinction between storm and tsunami effects on megaclasts, which is treated comprehensively in the article by Lorang [52]. Lubova et al. [8] explained the importance of large sedimentary particles with regard to geological heritage conservation and geotourism. There are also conceptual papers that deal with the other subjects, but also treat megaclasts as an important issue. A typical example is review of rocky coasts [74] where megaclasts are common sedimentary particles.

\section{Geological Spatio-Temporal Dimension of the Term Application}

Bibliographical information collected for the purposes of the present article permits consideration of spatio-temporal distribution of megaclasts. Indeed, the latter include only those large sedimentary particles termed as "megaclasts".

Megaclast-related articles fall into different intervals of geological history (Figure 3). Most often, these studies are drawn from very young formations of Quaternary age. For instance, there are megaclast accumulations in the coastal areas of Morocco that were produced by the mid-18th-century tsunami [56]. Paleozoic and Mesozoic megaclasts are rarely studied. Surprisingly, significant attention has been paid to Proterozoic megaclasts (Figure 3). These were examined in northwestern Canada [35,46,64,73], the Western United States [47,48], and the British Isles [41]. The Paleoproterozoic Wernecke Supergroup in Yukon and the Neoproterozoic Kingston Peak Formation in California provide representative examples of Precambrian megaclasts.

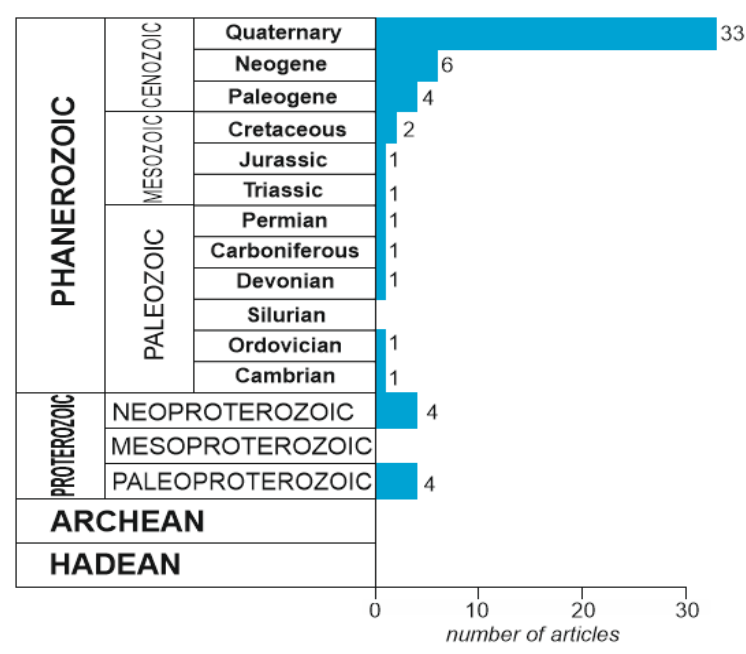

Figure 3. Geological age of megaclasts studied during 2000-2017; the geological time scale after Ogg et al. [80] (created by authors).

Megaclasts are reported from almost all continents and oceans (Figure 4). Most intensively, these were studied in five major regions of the world, namely West Europe, Australia and New Zealand, Western North America, Southern South America, and the Pacific and circum-Pacific. Best known are Quaternary megaclasts of the British Isles and New Zealand. The former were studied, particularly, by Scheffers et al. [69] and Williams and Hall [77], whereas Keigler et al. [44], Gaylor and Neall [36], and Roverato et al. [66] made a significant contribution to the knowledge of the latter. Interestingly, 
not only Quaternary, but also Paleogene and Neogene megaclasts were examined in New Zealand and, thus, the latter seems to have been the most important place for modern megaclast research because of successful locally-developed projects resulting in a series of publications.

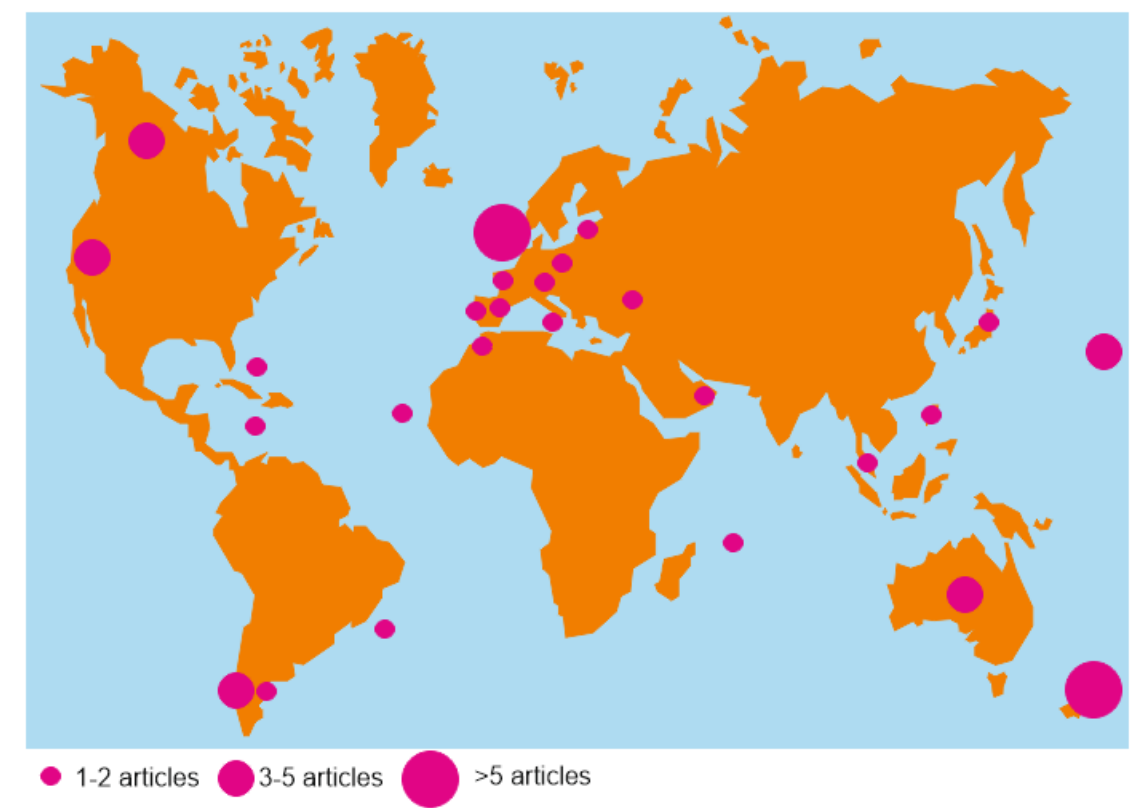

Figure 4. Geographical distribution of megaclasts studied during 2000-2017 (created by authors).

Megaclasts demonstrate an affinity to very different facies (Table 1). Most often, these occur near the shoreline, i.e., on beaches and inner shelves. In such cases, megaclasts are formed by rockfalls and rockslides on retreated cliffs and then transported by tsunami and storm waves. As such, rocky coasts open to oceans are the principal depositional environment for megaclast development. Typical examples are the coasts of Oahu [57,58], Oman [40], and Galicia [62]. Although megaclasts are large and heavy, these are often formed on destructed slopes and easily involved in the slope processes in continental and submarine environments. As a result, they are typical for colluvial deposits and also linked to volcanism-triggered debris flows and turbidites. Among other interesting phenomena, it is important to note links of some megaclasts with past glaciations-e.g., erratic megaclasts of Latvia described by Kalnina et al. [43] and gigantic Sturtian megaclasts South Australia mentioned by Preiss et al. [65] —and magma-water interaction in ancient basins—e.g., Ordovician megaclasts from the Argentina's Puna Highland [32]. Megaclasts can be produced by extraterrestrial impacts. On the Earth, this is reported by Salisbury et al. [67] in connection with the Lawn Hill circular structure in northwest Queensland (Australia). However, such an origin of megaclasts is most typical on various cosmic bodies [10]. Generally, megaclasts are produced by and involved in different geological processes, the best documented, but actually not all of which are summarized in Figure 5. 


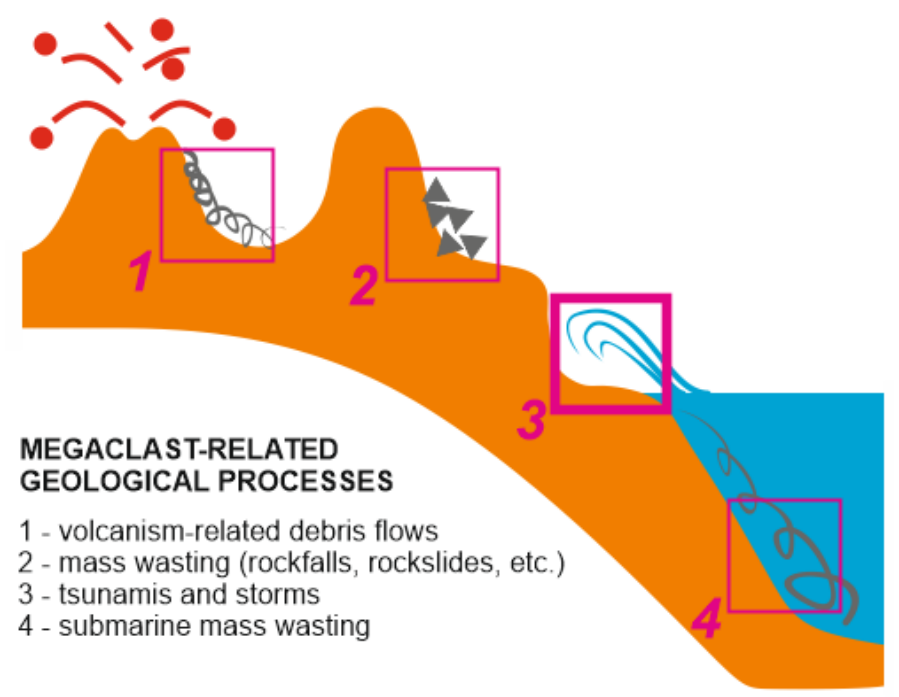

Figure 5. The main megaclast-related geological processes studied during 2000-2017; the bold frame indicates the most intensively studied processes (created by the authors).

\section{Discussion}

The present analysis implies that megaclast research has progressed since the beginning of the 21st century. However, the intensity of use of the term "megaclast" remains questionable. On one hand, the similarly-constrained search in the same bibliographical database demonstrates that the number of articles published annually on cobbles and pebbles was in 45 and 121 times greater, respectively than on megaclasts. On the other hand, cobbles and pebbles are significantly more common sedimentary particles, and these terms have been employed actively during the past century. In contrast, megaclasts are rare, and the term itself is new. In this case, it would be incorrect to say that modern megaclast research is low in intensity. However, this kind of research is likely to become more active in recognition of the largest stones on the Earth as megaclasts and to better understand their origin.

It should be stressed that the distribution of megaclasts in geological time and space considered above is deduced from only the article employing the term "megaclast". In such a case, further comparison of this documented distribution with the expected distribution of megaclasts termed so or not indicates on biases in use of the term "megaclast". Three kinds of biases, namely stratigraphical, geographical, and genetic biases can be detected, and these are discussed below.

The young age of the majority of studied megaclasts (Figure 3) implies their poor preservation in the geological record. Most probably, they are subject to weathering and erosion by water and wind, and so they disintegrate quickly into smaller particles over longer geological time scales. Megaclasts often occur on rocky shores, and the relevant facies are also uncommon in the geological record [81,82]. However, the recognition of Precambrian and early Paleozoic megaclasts implies that some of such large particles can be preserved under specific conditions, among which rapid sedimentation seems to be the most important. The distribution of megaclasts through the geological time as reflected by the published articles (Figure 3) may also be biased. If the relevant research is facilitated by an interest in modern and historical tsunamis, it is not strange that large clasts of chiefly Quaternary age are the main research focus in this trend.

The currently available knowledge of megaclast distribution (Figure 4) appears to be seriously biased. Studies in Russia [8], Iran [83], and Egypt [84,85] point out the existence of numerous megaclasts and their "fields" that are yet to attract any special investigation. Some impressive megaclasts are known as geotourist attractions in different parts of the world-e.g., the erratic block on Letipea Peninsula in Estonia [7], but these were not studied from a sedimentological point of view. Numerous large clasts on various cosmic bodies such as planets and satellites, asteroids, and comets have been recognized as megaclasts only very recently [10]. Undoubtedly, megaclast research should expand to 
the Arctic and Antarctica, Southern and Southeastern Asia, Africa, Central and Eastern Americas, etc., to fill existing geographical gaps. In other words, megaclasts known in these parts of the world should be termed properly, i.e., as megaclasts.

An analysis of the available literature sources (Table 1) demonstrates that the majority of studies focus more on the transport of megaclasts in a particular depositional environment than on their origin. This is a very significant research bias. Of course, tsunami-versus-storm debates relevant to transport of megaclasts on shores $[23,26]$ are important, but it often remains unclear how these megaclasts were formed initially. For instance, mechanisms revealed by Panek et al. [86] imply that megaclast formation may be not so simple and fast as one may expect. If so, megaclasts may remain "attached" to the place of their origin for some time. The other bias relevant to facies is linked to an evident over-emphasis on large clasts occurring on ocean coasts. Quaternary megaclasts linked to active volcanism in New Zealand [36,37] and the Paleoproterozoic megaclasts of Northwestern Canada [35,46,73] appear to be highly-specific in regard to their origin, transport, and mode of preservation. Much attention has been paid to them "occasionally", i.e., only because of the long-term research projects focused on unusual features of the host sedimentary complexes. In contrast, some other environments, in which megaclasts are thought to be common, have been investigated less intensively. The proposed scheme of the main megaclast-related geological processes that is based on the present literature review (Figure 5) fails to consider several important phenomena. Growth and retreat of continental ice sheets should produce significant number of erratic megaclasts that can be found, for instance, in northern Europe and northern North America. Large particles may be formed on some lake coasts with steep slopes formed of hard rocks such as granites. For instance, these can be studied on the shore of the Lake Malawi in Africa. Weathering can lead to appearance of megaclasts via gradual "sculpturing" from the parent rock, as this is described in Egypt by Sallam et al. [85]. Similarly, epikarst development may result in separation of large blocks because of joint-controlled grike growth, as this is known in the Lagonaki Highland of Russia (Figure 6). Road construction and other kinds of engineering works may result in the appearance of artificial megaclasts. Particularly, these were reported by Lubova et al. [8] from the Western Caucasus in Russia. Newly-formed and transported megaclasts should be differentiated. For instance, many megaclasts associated with storm and tsunami deposits were created via slope failure resulted from "normal" wave abrasion, not necessarily by big waves. Generally, the available knowledge of megaclast origin (Figure 5) appears to be strongly biased when compared to the more general genetic classification resulting from consideration of possible situations of megaclast formation and transport (Table 2). Additionally, it may be sensible to distinguish types of megaclasts depending on their lithological composition, i.e., siciciclastic, carbonate, mixed, etc. For instance, a typical carbonate megaclast is shown on Figure 1.

The wide application of the term "megaclast" is a relatively new trend, and many geologists, unfortunately, still avoid it. On the one hand, this narrows megaclasts research. On the other hand, such megaclasts that are not known as megaclasts should be re-considered. For the purposes of this brief review, it appears to be important to give several examples of important works that contribute potentially to megaclast research, although do not use the term "megaclast". Dott and Byers [87] in their description of the Cambrian strata of Wisconsin, the United States note the existence of some "boulders" that reach meters in diameter. Their origin is linked to palaeostorms. Johnson et al. [88] report large "boulders" in Pliocene massive delta outwash deposits on an island in the Gulf of California in Mexico, the formation of which was related to heavy, hurricane-related rain fall on land that cleared mountain canyons of rock debris. Rovere et al. [79] focus on Quaternary storm-related giant "boulders" of the Bahamas. Panek et al. [86] describe Quaternary formation of gigantic limestone blocks on the Crimean Peninsula linked to processes of karstification and the Black Sea transgression. The studies of Soukopova [89,90], Erdmann et al. [91], Hongo et al. [92], Johnson et al. [93], and Lau et al. [94] should also be noted. In all these cases, megaclasts are considered in fact. Some regions like Sicily in Italy [28,95-99] are well-known for large clast occurrence. Special attention should be paid to them in order to document these particles and to distinguish true megaclasts from boulders. Undoubtedly, the number of large clasts that are yet to be identified as megaclasts is significant. 


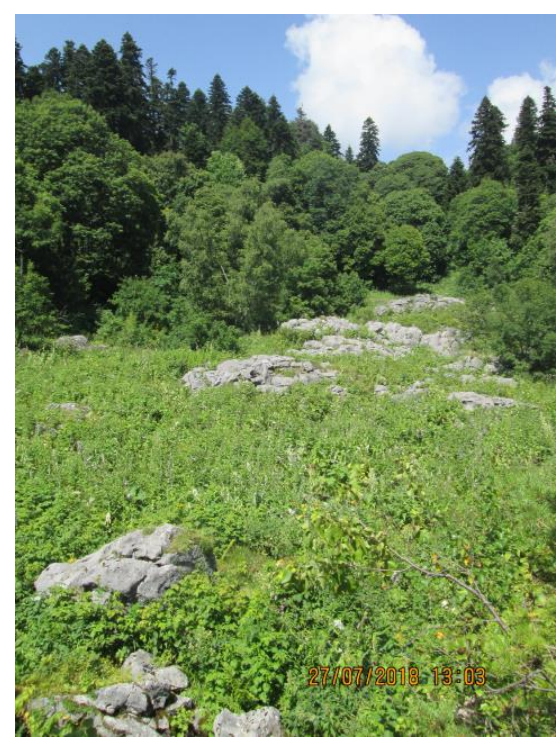

Figure 6. Megaclast formation as a result of carbonate karstification on the Lagonaki Highland in Russia (created by the author-D.A.R.).

Table 2. A tentative genetic classification of megaclasts; the sign "+" marks correspondence of the categories.

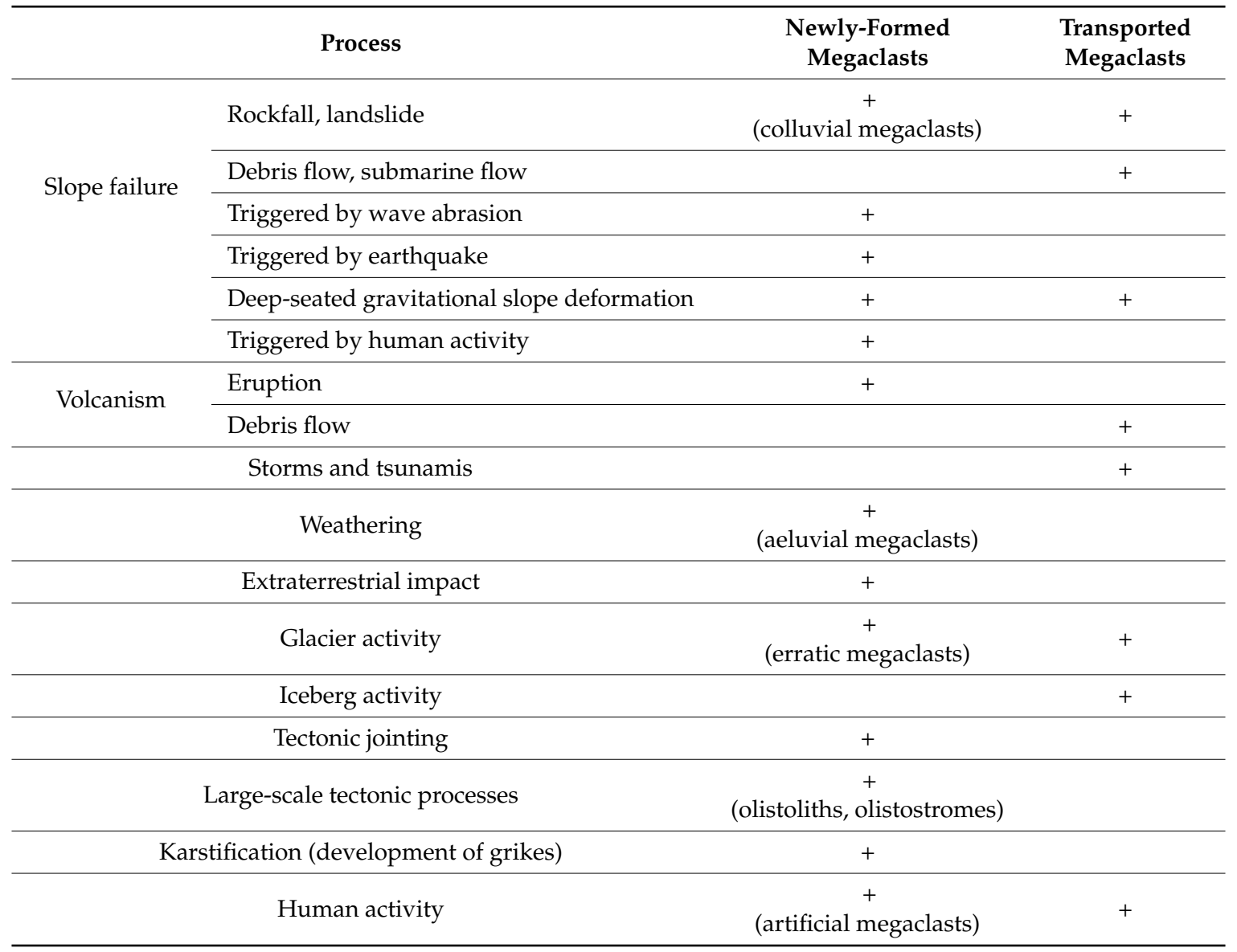

Note: this classification should be further justified and extended together with compilation of more genetic knowledge of megaclasts.

Surprisingly, there is also important evidence of megaclasts from tourism. Due to their physical and aesthetic parameters, megaclasts are often employed as tourist attractions [8]. A tentative analysis 
of Internet resources points to several impressive megaclasts occurrences in different countries; importantly, these include erratic clasts and clasts formed by erosion and weathering (Table 3). Moreover, some megaclasts serve as important elements of the local historical and cultural heritage. Typical examples are the gigantic erratic Thunder Stone used as the basis of the famous monument in the Russian city of Saint Petersburg (Figure 7A) and the stone erased to commemorate the historical foundation of the other Russian city of Cherepovets (Figure 7B). The both are essentially erratic megaclasts that experienced slight modification by artists. Apparently, these tourist attractions are almost totally missed from the field of the term use.

Table 3. Selected megaclasts used as tourist attractions.

\begin{tabular}{cccc}
\hline Name & Location & Origin & Notes \\
\hline $\begin{array}{c}\text { Ehalkivi (Sunset Glow } \\
\text { Boulder) }\end{array}$ & $\begin{array}{c}\text { Viru-Nigula Parish, } \\
\text { Lääne-Viru County } \\
\text { Estonia }\end{array}$ & Erratic & Height $7 \mathrm{~m}$ \\
\hline Devils Marbles & $\begin{array}{c}\text { Tennant Creek, Northern } \\
\text { Territory, Australia }\end{array}$ & Erosion & $\begin{array}{c}\text { Some clasts naturally balance on } \\
\text { one another }\end{array}$ \\
\hline Wairere Boulders & $\begin{array}{c}\text { Northland Region, New } \\
\text { Zealand }\end{array}$ & Erosion & $\begin{array}{c}\text { Clasts represent remnants of the } \\
\text { eroded basalt flow }\end{array}$ \\
\hline $\begin{array}{c}\text { Kummakivi } \\
\text { (Strange Stone) }\end{array}$ & $\begin{array}{c}\text { Ruokolahti, Finland } \\
\text { Unnamed }\end{array}$ & Erratic? & Length 7 m \\
\hline Sosio Megablock & Josef Land, Russia & Weathering? & Stone spheres up to $>1$ m in size \\
\hline $\begin{array}{c}\text { Krishna's Butterball } \\
\text { (Vaan Irai Kal) }\end{array}$ & $\begin{array}{c}\text { Mahabalipuram, Tamil } \\
\text { Nadu, India }\end{array}$ & Mass wasting & Permian limestones \\
\hline
\end{tabular}
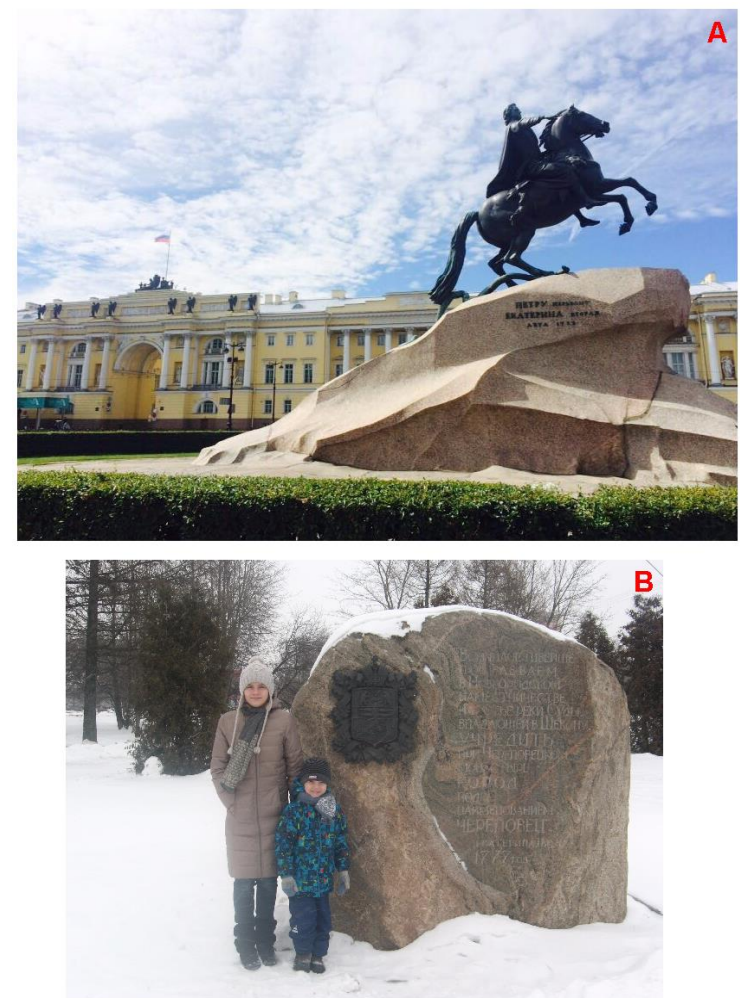

Figure 7. Examples of megaclasts in historical and cultural heritage: (A) the statue of Peter the Great, known also as the Bronze Horseman, in Saint Petersburg, Russia; and (B) the stone erased to commemorate the historical foundation of Cherepovets, Russia; people for scale (created by the authors: A-A.A.P., B-N.N.Y.). 


\section{Conclusions}

The present review allows five general conclusions to be made. The megaclast research has progressed significantly after the publication of a detailed classification for large sedimentary particles by Blair and McPherson [1], and the use of the term "megaclast" accelerated in the mid-2000s and the early 2010s. Although the age of megaclasts ranges from the Paleoproterozoic to the Present, the majority are of Quaternary in age, which reflects partly on the low preservation potential of very large sedimentary particles and partly the stratigraphical bias of the term use. The known geographical distribution of megaclasts with over-emphasis on West Europe, Australia, and New Zealand, Western North America, Southern South America, and the Pacific and circum-Pacific is strongly biased geographically. Megaclasts are studied in different facies and geological processes, among which rocky coasts, volcanism-triggered debris flows, and continental and submarine mass wasting are the best known; this is the other, genetic bias of the use of the term "megaclast". The proposed genetic classification of megaclasts implies a wider spectrum of depositional environments than emphasized in the literature. Erratic, karst-related, artificial, and some other megaclasts are mainly not termed as megaclasts, which is a kind of failure in the term use.

Generally, the present review shows that use of the term "megaclast" in the modern research is not only significantly restricted, but also biased. This makes the very knowledge of megaclasts incomplete despite two decades of investigations. Active application of the term is necessary to avoid current situation where we know about megaclasts defined as such and megaclasts defined somehow else or not defined specifically. Otherwise, the term should be abandoned, although this is not desirable because of its evident suitability. An important task for further research is understanding why researchers accept the term so slowly. This depends on finding more efficient ways for introduction of new terms in today's geoscience.

Author Contributions: Conceptualization: D.A.R. and N.N.Y.; methodology: D.A.R. and A.A.P.; investigation and writing: D.A.R., A.A.P., and N.N.Y.

Funding: This research received no external funding.

Acknowledgments: The authors gratefully thank the journal editors and four anonymous reviewers for their recommendations and support, as well as M. E. Johnson (United States) and S. O. Zorina (Russia) for their helpful suggestions to the preliminary versions of this paper. M. E. Johnson's stylistic and linguistic polishing of the manuscript is highly appreciated. The D.A.R.'s present and former colleagues and students from the Southern Federal University (Russia), including K. A. Lubova, are acknowledged for accompanying in the field and various assistance. Special thanks are addressed to N. V. Ruban and M. E. and D. E. Yashalov for assistance with making photos.

Conflicts of Interest: The authors declare no conflict of interest.

\section{References}

1. Blair, T.C.; McPherson, J.G. Grain-size and textural classification of coarse sedimentary particles. J. Sediment. Res. 1999, 69, 6-19. [CrossRef]

2. $\quad$ Farrell, K.M.; Harris, W.B.; Mallinson, D.J.; Culver, S.J.; Riggs, S.R.; Pierson, J.; Self-Trail, J.M.; Lautier, J.C. Standardizing texture and facies codes for a process-based classification of clastic sediment and rock. J. Sediment. Res. 2012, 82, 364-378. [CrossRef]

3. Lokier, S.W.; Al Junaibi, M. The petrographic description of carbonate facies: Are we all speaking the same language? Sedimentology 2016, 63, 1843-1885. [CrossRef]

4. Udden, J.A. The Mechanical Composition of Wind Deposits. Augustana Lib. Publ. 1898, 1, 1-69.

5. Wentworth, C.K. A scale of grade and class terms for clastic sediments. J. Geol. 1922, 30, 377-392. [CrossRef]

6. Ruban, D.A. Research in tsunami-related sedimentology during 2001-2010: Can a single natural disaster re-shape the science? GeoActa 2011, 10, 79-85.

7. Wimbledon, W.A.P.; Smith-Meyer, S. (Eds.) Geoheritage in Europe and Its Conservation; ProGEO: Oslo, Norway, 2012; pp. 1-405.

8. Lubova, K.A.; Zayats, P.P.; Ruban, D.A.; Tiess, G. Megaclasts in geoconservation: Sedimentological questions, anthropogenic influence, and geotourism potential. Geologos 2013, 19, 321-335. [CrossRef] 
9. Pajola, M.; Vincent, J.-B.; Guttler, C.; Lee, J.-C.; Bertini, I.; Massironi, M.; Simioni, E.; Marzari, F.; Giacomini, L.; Lucchetti, A.; et al. Size-frequency distribution of boulders $\geq 7 \mathrm{~m}$ on comet $67 \mathrm{P} /$ Churyumov-Gerasimenko. Astron. Astrophys. 2015, 583, A37. [CrossRef]

10. Bruno, D.E.; Ruban, D.A. Something more than boulders: A geological comment on the nomenclature of megaclasts on extraterrestrial bodies. Planet. Space Sci. 2017, 135, 37-42. [CrossRef]

11. Dhingra, D.; Head, J.W.; Pieters, C.M. Geological mapping of impact melt deposits at lunar complex craters Jackson and Tycho: Morphologic and topographic diversity and relation to the cratering process. Icarus 2017, 283, 268-281. [CrossRef]

12. Blair, T.C.; McPherson, J.G. Processes and forms of alluvial fans. In Geomorphology of Desert Environments; Parsons, A.J., Abrahams, A.D., Eds.; Springer: Dordrecht, The Netherlands, 2009; pp. 413-467.

13. Blott, S.J.; Pye, K. Particle size scales and classification of sediment types based on particle size distributions: Review and recommended procedures. Sedimentology 2012, 59, 2071-2096. [CrossRef]

14. Terry, J.P.; Goff, J. Megaclasts: Proposed revised nomenclature at the coarse end of the Udden-Wentworth grain-size scale for sedimentary particles. J. Sediment. Res. 2014, 84, 192-197. [CrossRef]

15. Dow, D.B. Evidence of a Late Pre-Cambrian Glaciation in the Kimberley Region of Western Australia. Geol. Mag. 1965, 102, 407-414. [CrossRef]

16. Swift, D.J.P.; Heron, S.D., Jr. Tidal deposits in the cretaceous of the Carolina coastal plain. Sediment. Geol. 1967, 1, 259-282. [CrossRef]

17. Stauffer, P.H.; Snelling, N.J. A Precambrian trondhjemite boulder in Palaeozoic mudstones of NW Malaya. Geol. Mag. 1977, 114, 479-482. [CrossRef]

18. Diffendal, R.F., Jr. Megaclasts in alluvial fills from the Ogallala Group (Miocene), Banner, Kimball, and Morrill counties, Nebraska. Contrib. Geol. Univ. Wyo. Laram. 1983, 22, 109-115.

19. Postma, G.; Nemec, W.; Kleinspehn, K.L. Large floating clasts in turbidites: A mechanism for their emplacement. Sediment. Geol. 1988, 58, 47-61. [CrossRef]

20. Heubeck, C. Sedimentology of large olistoliths, southern Cordillera Central, Hispaniola. J. Sediment. Petrol. 1992, 62, 474-482.

21. Kirillova, K.; Fu, X.; Lehto, X.; Cai, L. What makes a destination beautiful? Dimensions of tourist aesthetic judgment. Tour. Manag. 2014, 42, 282-293. [CrossRef]

22. Qiu, H.-H.; Liu, L.-G. A Study on the Evolution of Carbon Capture and Storage Technology Based on Knowledge Mapping. Energies 2018, 11, 1103. [CrossRef]

23. Paris, R.; Naylor, R.A.; Stephenbson, W.J. Boulders as signatures of storms on rock coasts. Mar. Geol. 2011, 283, 1-11. [CrossRef]

24. Paris, R.; Ramalho, R.S.; Madeira, J.; Avila, S.; May, S.M.; Rixhon, G.; Engel, M.; Bruckner, H.; Herzog, M.; Schukraft, G.; et al. Mega-tsunami conglomerates and flank collapses of ocean island volcanoes. Mar. Geol. 2018, 395, 168-187. [CrossRef]

25. Ramalho, R.S.; Winckler, G.; Madeira, G.; Helffrich, G.R.; Hipolito, A.; Quartau, R.; Adena, K.; Schaefer, J.M. Hazard potential of volcanic flank collapses raised by new megatsunami evidence. Sci. Adv. 2015, 1, e1500456. [CrossRef] [PubMed]

26. Hearty, P.J.; Tormey, B.R. Sea-level change and superstorms; geologic evidence from the last interglacial (MIS 5e) in the Bahamas and Bermuda offers ominous prospects for a warming Earth. Mar. Geol. 2017, 390, 347-365. [CrossRef]

27. Cox, R.; Jahn, K.J.; Watkins, O.G.; Cox, P. Extraordinary boulder transport by storm waves (west of Ireland, winter 2013-2014), and criteria for analysing coastal boulder deposits. Earth-Sci. Rev. 2018, 177, 623-636. [CrossRef]

28. Barbano, M.S.; Pirrotta, C.; Gerardi, F. Large boulders along the south-eastern Ionian coast of Sicily: Storm or tsunami deposits? Mar. Geol. 2010, 275, 140-154. [CrossRef]

29. Canto, A.P.B.; Padrones, J.T.; Concepcion, R.A.B.; Perez, A.D.C.; Tamayo, R.A.; Dimalanta, C.B.; Faustino-Eslava, D.V.; Queano, K.L.; Yumul, G.P. Geology of northwestern Mindoro and its offshore islands: Implications for terrane accretion in west Central Philippines. J. Asian Earth. Sci. 2012, 61, 78-87. [CrossRef]

30. Carpentier, C.; Lathuiliere, B.; Ferry, S. The Oxfordian carbonate platform of Lorraine: Evidences for an opening toward the Germanic Sea. Comptes Rendus Geosci. 2004, 336, 59-66. [CrossRef]

31. Choe, M.Y.; Sohn, Y.K.; Jo, H.R.; Kim, Y. Sedimentary facies and evolution of the Cretaceous deep-sea channel system in Magallanes Basin, southern Chile. Ocean Polar Res. 2004, 26, 385-400. [CrossRef] 
32. Coira, B.; Perez, B. Peperitic textures of Ordovician dacitic synsedimentary intrusions in Argentina's Puna Highland: Clues to emplacement conditions. J. Volcanol. Geotherm. Res. 2002, 114, 165-180. [CrossRef]

33. Dewey, J.F.; Ryan, P.D. Storm, rogue wave, or tsunami origin for megaclast deposits in western Ireland and North Island, New Zealand? Proc. Natl. Acad. Sci. USA 2017, 114, E10639-E10647. [CrossRef] [PubMed]

34. Engel, M.; May, S.M. Bonaire's boulder fields revisited: Evidence for Holocene tsunami impact on the Leeward Antilles. Quat. Sci. Rev. 2012, 54, 126-141. [CrossRef]

35. Furlanetto, F.; Thorkelson, D.J.; Daniel Gibson, H.; Marshall, D.D.; Rainbird, R.H.; Davis, W.J.; Crowley, J.L.; Vervoort, J.D. Late Paleoproterozoic terrane accretion in northwestern Canada and the case for circum-Columbian orogenesis. Precambrian Res. 2013, 224, 512-528. [CrossRef]

36. Gaylord, D.R.; Neall, V.E. Subedifice collapse of an andesitic stratovolcano: The maitahi formation, Taranaki Peninsula, New Zealand. Bull. Geol. Soc. Am. 2012, 124, 181-199. [CrossRef]

37. Gaylord, D.R.; Neall, V.E.; Palmer, A.S. The middle Pleistocene Maitahi Formation, Taranaki, New Zealand: A new formal lithostratigraphic unit. N. Z. J. Geol. Geophys. 2014, 57, 369-377. [CrossRef]

38. Goff, J.; Terry, J.P. Tsunamigenic slope failures: The Pacific Islands 'blind spot'? Landslides 2016, 13, $1535-1543$. [CrossRef]

39. Hall, A.M.; Hansom, J.D.; Williams, D.M. Wave-emplaced coarse debris and megaclasts in Ireland and Scotland: Boulder transport in a high-energy littoral environment: A discussion. J. Geol. 2010, 118, 699-704. [CrossRef]

40. Hoffmann, G.; Reicherter, K.; Wiatr, T.; Grutzner, C.; Rausch, T. Block and boulder accumulations along the coastline between Fins and Sur (Sultanate of Oman): Tsunamigenic remains? Nat. Hazards 2013, 65, 851-873. [CrossRef]

41. Horak, J.M.; Evans, J.A. Early Neoproterozoic limestones from the Gwna Group, Anglesey. Geol. Mag. 2011, 148, 78-88. [CrossRef]

42. Jackson, C.A.-L. Three-dimensional seismic analysis of megaclast deformation within a mass transport deposit; Implications for debris flow kinematics. Geology 2011, 39, 203-206. [CrossRef]

43. Kalnina, L.; Strautnieks, I.; Cerina, A. Upper Pleistocene biostratigraphy and traces of glaciotectonics at the Satiki site, western Latvia. Quat. Int. 2007, 164-165, 197-206. [CrossRef]

44. Keigler, R.; Thouret, J.-C.; Hodgson, K.A.; Neall, V.E.; Lecointre, J.A.; Procter, J.N.; Cronin, S.J. The Whangaehu Formation: Debris-avalanche and lahar deposits from ancestral Ruapehu volcano, New Zealand. Geomorphology 2011, 133, 57-79. [CrossRef]

45. Laird, M.G.; Bassett, K.N.; Schioler, P.; Morgans, H.E.G.; Bradshaw, J.D.; Weaver, S.D. Paleoenvironmental and tectonic changes across the Cretaceous/Tertiary boundary at Tora, southeast Wairarapa, New Zealand: A link between Marlborough and Hawke's Bay. N. Z. J. Geol. Geophys. 2003, 46, 275-293. [CrossRef]

46. Laughton, J.R.; Thorkelson, D.J.; Brideau, M.-A.; Hunt, J.A.; Marshall, D.D. Early Proterozoic orogeny and exhumation of Wernecke Supergroup revealed by vent facies of Wernecke Breccia, Yukon, Canada. Can. J. Earth Sci. 2005, 42, 1033-1044. [CrossRef]

47. Le Heron, D.P.; Busfield, M.E.; Prave, A.R. Neoproterozoic ice sheets and olistoliths: Multiple glacial cycles in the Kingston Peak Formation, California. J. Geol. Soc. 2014, 171, 525-538. [CrossRef]

48. Le Heron, D.P.; Tofaif, S.; Vandyk, T.; Ali, D.O. A diamictite dichotomy: Glacial conveyor belts and olistostromes in the Neoproterozoic of Death Valley, California, USA. Geology 2017, 45, 31-34. [CrossRef]

49. Le Roux, J.P. A critical examination of evidence used to re-interpret the hornitos mega-breccia as a mass-flow deposit caused by cliff failure. Andean Geol. 2015, 42, 139-145.

50. Le Roux, J.P.; Vargas, G. Hydraulic behavior of tsunami backflows: Insights from their modern and ancient deposits. Environ. Geol. 2005, 49, 65-75. [CrossRef]

51. Lecointre, J.A.; Neall, V.E.; Wallace, C.R.; Prebble, W.M. The 55- to 60-ka Te Whaiau Formation: A catastrophic, avalanche-induced, cohesive debris-flow deposit from Proto-Tongariro volcano, New Zealand. Bull. Volcanol. 2002, 63, 509-525. [CrossRef]

52. Lorang, M.S. A wave-competence approach to distinguish between boulder and megaclast deposits due to storm waves versus tsunamis. Mar. Geol. 2011, 283, 90-97. [CrossRef]

53. Madon, M. Submarine mass-transport deposits in the Semantan Formation (Middle-Upper Triassic), central Peninsular Malaysia. Bull. Geol. Soc. Malays. 2010, 56, 15-26.

54. Martin-Merino, G.; Fernandez, L.P.; Colmenero, J.R.; Bahamonde, J.R. Mass-transport deposits in a Variscan wedge-top foreland basin (Pisuerga area, Cantabrian Zone, NW Spain). Mar. Geol. 2014, 356, 71-87. [CrossRef] 
55. McKee, J.W.; McKee, M.B.; Anderson, T.H. Mesozoic basin formation, mass-gravity sedimentation, and inversion in northeastern Sonora and southeastern Arizona. Spec. Pap. Geol. Soc. Am. 2005, 393, 481-507. [CrossRef]

56. Medina, F.; Mhammdi, N.; Chiguer, A.; Akil, M.; Jaaidi, E.B. The Rabat and Larache boulder fields; new examples of high-energy deposits related to storms and tsunami waves in north-western Morocco. Nat. Hazards 2011, 59, 725-747. [CrossRef]

57. Noormets, R.; Felton, E.A.; Crook, K.A.W. Sedimentology of rocky shorelines: 2 Shoreline megaclasts on the north shore of Oahu, Hawaii-Origins and history. Sediment. Geol. 2002, 150, 31-45. [CrossRef]

58. Noormets, R.; Crook, K.A.W.; Felton, E.A. Sedimentology of rocky shorelines: 3. Hydrodynamics of megaclast emplacement and transport on a shore platform, Oahu, Hawaii. Sediment. Geol. 2004, 172, 41-65. [CrossRef]

59. Oliveira, M.A.; Andrade, C.; Freitas, M.C.; Costa, P.; Taborda, R.; Janardo, C.; Neves, R. Transport of large boulders quarried from shore platforms of the Portuguese west coast. J. Coast. Res. 2011, 64, 1871-1875.

60. Ortiz-Karpf, A.; Hodgson, D.M.; McCaffrey, W.D. The role of mass-transport complexes in controlling channel avulsion and the subsequent sediment dispersal patterns on an active margin: The Magdalena Fan, offshore Colombia. Mar. Petrol. Geol. 2015, 64, 58-751. [CrossRef]

61. Paris, R.; Kelfoun, K.; Giachetti, T. Marine conglomerate and reef megaclasts at Mauritus island: Evidences of a tsunami generated by a flank collapse of the Piton de la Fournaise volcano, Reunion Island? Sci. Tsunami Hazards 2013, 32, 281-291.

62. Perez-Alberti, A.; Trenhaile, A.S.; Pires, A.; Lopez-Bedoya, J.; Chamine, H.I.; Gomes, A. The effect of boulders on shore platform development and morphology in Galicia, north west Spain. Cont. Shelf Res. 2012, 48, 122-137. [CrossRef]

63. Pierre, G. Processes and rate of retreat of the clay and sandstone sea cliffs of the northern Boulonnais (France). Geomorphology 2006, 73, 64-77. [CrossRef]

64. Pope, M.C.; Grotzinger, J.P. Paleoproterozoic Stark Formation, Athapuscow Basin, northwest Canada: Record of cratonic-scale salinity crisis. J. Sediment. Res. 2003, 73, 280-295. [CrossRef]

65. Preiss, W.V.; Gostin, V.A.; McKirdy, D.M.; Ashley, P.M.; Williams, G.E.; Schmidt, P.W. The glacial succession of Sturtian age in South Australia: The Yudnamutana Subgroup. Geo. Soc. Mem. 2011, 36, 701-712. [CrossRef]

66. Roverato, M.; Cronin, S.; Procter, J.; Capra, L. Textural features as indicators of debris avalanche transport and emplacement, Taranaki volcano. Bull. Geol. Soc. Am. 2015, 127, 3-18. [CrossRef]

67. Salisbury, J.A.; Tomkins, A.G.; Schaefer, B.F. New insights into the size and timing of the Lawn Hill impact structure: Relationship to the Century Zn-Pb deposit. Aust. J. Earth Sci. 2008, 55, 587-603. [CrossRef]

68. Scheffers, S.R.; Scheffers, A.; Kelletat, D.; Bryant, E.A. The Holocene paleo-tsunami history of West Australia. Earth Planet. Sci. Lett. 2008, 270, 137-146. [CrossRef]

69. Scheffers, A.; Scheffers, S.; Kelletat, D.; Browne, T. Wave-emplaced coarse debris and megaclasts in Ireland and Scotland: Boulder transport in a high-energy littoral environment. J. Geol. 2009, 117, 553-573. [CrossRef]

70. Scheffers, A.; Kelletat, D.; Scheffers, S. Wave-emplaced coarse debris and megaclasts in Ireland and Scotland: Boulder transport in a high-energy littoral environment: A reply. J. Geol. 2010, 118, 705-709. [CrossRef]

71. Shane, P.; Strachan, L.J.; Smith, I. Redefining the Waitemata Basin, New Zealand: A new tectonic, magmatic, and basin evolution model at a subduction terminus in the SW Pacific. Geochem. Geophys. Geosyst. 2010, 11, Q04008. [CrossRef]

72. Suttner, T.J.; Kido, E. Distinct sea-level fluctuations and deposition of a megaclast horizon in the neritic Rauchkofel Limestone (Wolayer area, Carnic Alps) correlate with the Lochkov-Prag Event. Geol. Soc. Lond. Spec. Publ. 2016, 423, 11-23. [CrossRef]

73. Thorkelson, D.J.; Laughton, J.R. Paleoproterozoic closure of an Australia-Laurentia seaway revealed by megaclasts of an obducted volcanic arc in Yukon, Canada. Gondwana Res. 2016, 33, 115-133. [CrossRef]

74. Trenhaile, A. Rocky coasts-Their role as depositional environments. Earth-Sci. Rev. 2016, 159, 1-13. [CrossRef]

75. Weckwerth, P.; Pisarska-Jamrozy, M. Periglacial and fluvial factors controlling the sedimentation of Pleistocene breccia in NW Poland. Geogr. Ann. Ser. A Phys. Geogr. 2015, 97, 415-430. [CrossRef]

76. Williams, D.M. Mechanisms of wave transport of megaclasts on elevated cliff-top platforms: Examples from western Ireland relevant to the storm-wave versus tsunami controversy. Ir. J. Earth Sci. 2010, 28, 13-23. [CrossRef] 
77. Williams, D.M.; Hall, A.M. Cliff-top megaclast deposits of Ireland, a record of extreme waves in the North Atlantic-Storms or tsunamis? Mar. Geol. 2004, 206, 101-117. [CrossRef]

78. Yagishita, K.; Komori, K. Basin evolution within the Kitakami Massif, northeast Japan: Relationship between sedimentation, tectonics and volcanism in an incipient Neogene continental back-arc basin. Sediment. Geol. 2000, 133, 7-26. [CrossRef]

79. Rovere, A.; Casella, E.; Harris, D.L.; Lorscheid, T.; Nandasena, N.A.K.; Dyer, B.; Sandstrom, M.R.; Stocchi, P.; D'Andrea, W.J.; Raymo, M.E. Giant boulders and Last Interglacial storm intensity in the North Atlantic. Proc. Natl. Acad. Sci. USA 2017, 114, 12144-12149. [CrossRef]

80. Ogg, J.G.; Ogg, G.M.; Gradstein, F.M. A Concise Geologic Time Scale 2016; Elsevier: Amsterdam, The Netherlands, 2016; pp. 1-234.

81. Johnson, M.E. Why are ancient rocky shores so uncommon? J. Geol. 1988, 96, 469-480. [CrossRef]

82. Johnson, M.E. Uniformitarianism as a guide to rocky-shore ecosystems in the geological record. Can. J. Earth Sci. 2006, 43, 1119-1147. [CrossRef]

83. Habibi, T.; Golubova, N.V.; Ruban, D.A. New evidence of highly-complex geological heritage in Iran: Miocene sections in the Zagros Fold-Thrust Belt. GeoResJ 2017, 13, 96-102. [CrossRef]

84. Sallam, E.S.; Ponedelnik, A.A.; Tiess, G.; Yashalova, N.N.; Ruban, D.A. The geological heritage of the Kurkur-Dungul area in southern Egypt. J. Afr. Earth Sci. 2018, 137, 103-115. [CrossRef]

85. Sallam, E.S.; Fathy, E.E.; Ruban, D.A.; Ponedelnik, A.A.; Yashalova, N.N. Geological heritage diversity in the Faiyum Oasis (Egypt): A comprehensive assessment. J. Afr. Earth Sci. 2018, 140, 212-224. [CrossRef]

86. Panek, T.; Lenart, J.; Hradecky, J.; Hercman, H.; Braucher, R.; Silhan, K.; Skarpich, V. Coastal cliffs, rock-slope failures and Late Quaternary transgressions of the Black Sea along southern Crimea. Quat. Sci. Rev. 2018, 181, 76-92. [CrossRef]

87. Dott, R.H., Jr.; Byers, C.W. Cambrian geology of the Baraboo Hills. Field Guide 2016, 43, 47-54. [CrossRef]

88. Johnson, M.E.; Ledesma-Vazques, J.; Backus, D.H. Tectonic Decapitation of a Pliocene Mega-Delta on Isla Del Carmen in the Gulf of California (Mexico): And a River Ran through it. J. Geol. 2016, 124, 55-74. [CrossRef]

89. Soukopova, J. Central Saharan rock art: Considering the kettles and cupules. J. Arid Environ. 2017, 143, 10-14. [CrossRef]

90. Soukopova, J. Decorated boulders and other neglected features of the Central Saharan rock art. J. Arid Environ. 2018, 156, 96-105. [CrossRef]

91. Erdmann, W.; Kelletat, D.; Scheffers, A. Boulder transport by storms-Extreme-waves in the coastal zone of the Irish west coast. Mar. Geol. 2018, 399, 1-13. [CrossRef]

92. Hongo, C.; Kurihara, H.; Golbuu, Y. Coral boulders on Melekeok reef in the Palau Islands: An indicator of wave activity associated with tropical cyclones. Mar. Geol. 2018, 399, 14-22. [CrossRef]

93. Johnson, M.E.; Ledesma-Vazquez, J.; Guardado-France, R. Coastal Geomorphology of a Holocene Hurricane Deposit on a Pleistocene Marine Terrace from Isla Carmen (Baja California Sur, Mexico). J. Mar. Sci. Eng. 2018, 6, 108. [CrossRef]

94. Lau, A.Y.A.; Terry, J.P.; Ziegler, A.; Pratap, A.; Harris, D. Boulder emplacement and remobilisation by cyclone and submarine landslide tsunami waves near Suva City, Fiji. Sediment. Geol. 2018, 364, 242-257. [CrossRef]

95. Spatola, D.; Micallef, A.; Sulli, A.; Basilone, L.; Ferreri, R.; Basilone, G.; Bonanno, A.; Pulizzi, M.; Mangano, S. The Graham Bank (Sicily Channel, central Mediterranean Sea): Seafloor signatures of volcanic and tectonic controls. Geomorphology 2018, 318, 375-389. [CrossRef]

96. Basilone, L. Mesozoic tectono-sedimentary evolution of Rocca Busambra in western Sicily. Facies 2009, 55, 115-135. [CrossRef]

97. Basilone, L.; Di Maggio, C. Geology of Monte Gallo (Palermo Mts, NW Sicily). J. Maps 2016, 12, $1072-1083$. [CrossRef]

98. Basilone, L.; Frixa, A.; Trincianti, E.; Valenti, V. Permian-Cenozoic deep-water carbonate rocks of the Southern Tethyan Domain. The case of Central Sicily. Ital. J. Geosci. 2016, 135, 171-198. [CrossRef]

99. Jones, W.T.; Feldmann, R.M.; Schweitzer, C.E.; Reitano, A.; Insacco, G. New Pygocephalomorph (Peracarida) from the Permian of the Sosio Valley (Sicily, Italy). J. Crustac. Biol. 2015, 35, 627-632. [CrossRef]

(C) 2018 by the authors. Licensee MDPI, Basel, Switzerland. This article is an open access article distributed under the terms and conditions of the Creative Commons Attribution (CC BY) license (http:/ / creativecommons.org/licenses/by/4.0/). 